\title{
Banks’ Earnings, Risks and Returns in China
}

\author{
Cheng Fan Fah, Annuar Nasir \\ University Putra Malaysia, Serdang, Selangor, Malaysia
}

\begin{abstract}
This study aims to find the effect of financial risks, price risks and market risks on the Earning Response Coefficients (ERC) for China Commercial Banks. The research methodologies use the traditional cumulative abnormal returns and the unexpected earning as the main dependent and independent variables. The evidences show that: (1) There is a strong returns-to-earnings relation for banks; (2) The liquidity risk has information content beyond earnings changes in the returns-to-earnings relation. This probably due to the reason that managers of banks find the level of liquidity that fulfilled the need of investors and at the same time earns good profits for the banks.
\end{abstract}

Keywords: earnings response coefficients, liquidity, credit, interest, solvency risk

\section{Introduction}

Most commercial banks in the world are operating in free enterprise system. However, China banking system was following a mono bank model before 1978, where People Bank of China (PBOC) combined the roles of central and commercial banking. All the banks which were taken over or restructured into PBOC system or under PBOC administration or Ministry of Finance to ensure the national production plans would be fulfilled with no incentives to compete with one another. Throughout the history of the People's Republic, the banking system has exerted close control over financial transactions and the money supply.

The reformation after 1978 had expanded the banking system by establishing several large state-owned banks: The Bank of China (BOC, 1912), China Construction Bank (CCB, 1954), Agricultural Bank of China (ABC, 1979), and Industrial and Commercial Bank of China (ICBC, 1984). These banks splitting the lending functions from the PBOC were initially designated to serve their sector of economy. In the mid-1980s the banking system still lacked some of the services and characteristics that were considered basic in most countries. Interbank relations were very limited, and interbank borrowing and lending was virtually unknown. Checking accounts were used by very few individuals, and bank credit cards did not exist. By 1985, the big four banks were allowed to compete in all sectors, but their competition among them was limited because they served mainly as policy lending “conduits” for the government and lacked incentive to compete until mid 1990s (Yang, 2002).

PBOC has encouraged banks to diversify their portfolios by increasing their services to the private sector and individual consumers. By July 2000, a personal credit rating system was launched in Shanghai to be used to assess consumer credit risk and set ratings standards. This is an important move in developing China's consumer credit industry, and increase bank loans to individuals.

The government of China has allowed several small banks to raise capital through bonds or stock issues.

Cheng Fan Fah, associate professor, Department of Economics, Faculty of Economics and Management, University Putra Malaysia. Annuar Nasir, dean, professor, Faculty of Economics and Management, University Putra Malaysia. 
Followed the listing of Shenzhen Development Bank and Pudong Development Bank, China Minsheng Bank, then the only private bank in China, was listed on the Shanghai Stock Exchange in December 2000. There were many more banks got listed after that (see section 3 on the sample of banks).

Years of government-directed lending has presented Chinese banks with large amounts of non-performing loans. According to the PBOC Bank's report, non-performing loans account for $21.4 \%$ to $26.1 \%$ of total lending of China's four big banks in 2002. In 1999, four asset management companies (AMC) were formed to repackage the non-performing loans into viable assets and sell them off to the investors. Therefore, the research questions are (1) What is the current financial situation of China commercial banks? (2) Which risk factors are significant in the earnings-returns relationship?

The objective of this paper is to investigate the effects of financial risks on earnings response for China commercial banks. Specifically, the study will examine the relationship of standardized unexpected earnings, interest risk, liquidity risk, credit risk, solvency risk, stock price risk, market risk and exchange rate risk with the abnormal returns of these banks.

The paper is divided into four chapters. Section 2 deals with the literature review. Section 3 contains an explanation of the research design, hypotheses, data and variable selection: Methodological issues were also discussed. The findings and discussion were presented in section 4 while paper end with conclusions in section 5 .

\section{Literature Review}

A body of accepted findings has emerged in the institutionally more developed capital markets from the research following that lead from two pioneering studies (Ball \& Brown, 1968; Beaver, Clarke, \& Wright, 1979) about the common stock price revaluation effect from changes in accounting earnings. The previous study focuses on common stock price direction from magnitude of earnings changes. The latter study focuses on documented the magnitude of common stock price changes arising from magnitude of earnings changes. A strong and significant response in the form of risk-adjusted share price changes in studies using quarterly earnings changes immediately around the date of announcement of earnings changes will be appeared. This was proved by a very high rank correlation ranging from 0.85 to 1.00 in the US capital market in the strength of the relation. There are similar findings with substantial revaluation effect contingent on accounting earnings changes was revealed in the findings in other developed capital markets (Cheng \& Ariff, 2007).

The modest attempt to answer whether the accepted findings in several institutionally more developed capital markets about the relevance of accounting earnings by Cheng, Arif and Shamsher (2001): There are some 70 emerging markets in the world, and the literature on these markets is growing steadily. The relation between changes in unexpected earnings and share price changes in US markets was measured using firms had been shown in that study. Although a significant price-to-earnings relation is evident, but consistency and magnitude of the relation were not as large as those reported in any institutionally more developed markets. If price reaction is measured over long periods the price adjustment is stronger. This shows that emerging markets may be a place of speculative trading. Others studies on similar topics are Hagerman, Zmijewski and Shah (1984), Ariff, Loh and Chew (1997) and Ball, Kothari and Watts (1993). The returns-to-earnings relation over the past 30 years have provided evidence that earnings and earnings related information explains stock returns had been shown on above studies.

One of the more striking consequences of the 2007-2009 financial crises has been the collapse of lending 
in the U.S. According to the IFS data, private sector credit from commercial banks slowed from annual rates of $8 \%$ or greater from 2003 through the first quarter of 2008 , to just over $2 \%$ by the end of 2008 , and thereafter actually registered negative growth for the first time in the decade. By referring to quarterly bank-specific data for the largest 100 U.S. banks, Barajas, Chami, Cosimano, and Hakura (2010) find that capital, rather than liquidity, constrained their lending. This may be in part because the liquidity measures do not adequately capture the effect of the collapse of the repo market. Banks took actions to increase capital both by (1) slowing the growth of lending and (2) raising profit margins by not fully passing through the Federal Reserve's cuts in the cost of funding. U.S. banks are found to optimally choose capital based on the expected demand for loans in the future and the marginal cost of holding capital.

There are several studies have analyzed the four financial risks, which is credit risk, interest risk, solvency risk and liquidity risk on the earnings response coefficients and the relationship between these effects on the stock pricing and returns. A multi-factor model to examine the interest rate sensitivity of a financial intermediary's common stock and re-specify in an attempt to estimate each factor's influence was used by Giliberto (1985). The joint interaction of exchange rate and interest rates on bank stock pricing was analysed by Choi, Elyasiani and Kopecky (1992). Faff and Howard (1999) examined the relationship between interest rate's changes and the returns on the shares of Australia banks and finance companies. Dennis and Jeffrey (2002) relate the common stock returns of publicly traded Australia banks to a market index, interest rate, and the trade-weighted Australia dollar exchange rate.

The relationship between default risk and firm size, book-to-market ratio and stock returns during a severe crisis was studied by Bystrom, Worasinchai and Chongsithipol (2005). Cheng and Ariff (2007) examine whether four financial risk factors correlated with the abnormal return of bank shares. There had mixed results in finding difference factors affecting the banks performances on all above studies.

In this study, we extend the research on the earnings respond coefficient to China banks which have developed and expended rapidly. This study examine 6 risks in China banks that are interest risk, solvency risk, liquidity risk, credit risk, price risk and market risk. Should the financial risks effect the banks stock revaluation similar to studies in United States, Australia and other part of the world? Do the bank managers and regulators able to convince their investors that earnings and earnings alone are the only facts to consider for bank stocks' valuation? In order to extend the literature to settle this contestability issue of theory to banking firms, which are different in many respects is worthwhile to carry out this type of research.

\section{Research Methodology}

\section{Research Design}

Many previous studies on earnings response acknowledged on the existence of strong correlations among the changes in stock price and the changes of earnings. This research is to study the impact of earnings to share price for China commercial banks and the magnitude of earnings response coefficient that stock prices change affects by risk determinants.

\footnotetext{
Abnormal Return

The abnormal return was calculated by using the difference between current year return and previous year return and which is commonly used in accounting literature. Sharpe's (1964) Market Model: Analysis of Abnormal Returns as a standard general equilibrium relationship for asset returns was used. Abnormal Returns
} 
(AR) are:

$$
A R_{i t}=R_{i t}-\left[\alpha_{i}+\beta_{i t} R_{m t}\right]
$$

with $R_{i t}=\left(P_{i t}-P_{i t-1}\right) / P_{i t-1}$ and $R_{m t}=\left(I_{t}-I_{t-1}\right) / I_{t-1}$. In addition, $I$ referred to market's composite index. The market parameters $\alpha_{i}$ and $\beta_{i t}$ were estimated by ordinary least square regression over trading periods, -71 months to -11 months (parameter estimation period) relative to the announcement month. The windows of analysis for the ARs were taken as 12 months. The windows of analysis were from the month of earnings announcements to 11 months before the announcements.

\section{Analysis of Unexpected Annual Accounting Earnings}

Unexpected annual earnings were computed using the naive expectation model, which assumed that the next period's expectation is simply the current period's annual earnings. This was consistent with the study to investigate the effect of price changes at a point in time. Unexpected annual earnings (UEs) were computed using naive model:

$$
U E_{i t}=\left[E_{i t}-E_{i(t-1)}\right] / E_{i(t-1)}
$$

To study the returns-to-earnings relation, the coefficient was tested in the regression analysis between unexpected earnings as independent variable and abnormal return as the dependent variables. The significance of the slope coefficient $(b)$ and the coefficient of the determination or the $R$ square were used to measure the inferences regarding the information content of annual earnings. The model being used:

$$
C A R_{i}=\beta_{0}+\beta_{1} * U E_{i}+\varepsilon_{i}
$$

where,

$C A R_{i}$ : Cumulative abnormal returns over 12 month's window;

$U E$ : Unexpected annual earnings;

$\varepsilon_{i}$ : A random disturbance term assumed to be normally distributed.

The slope coefficient of the regression $\beta_{l}$ is called the Earnings Response Coefficient (ERC).

\section{Risk Determinant Factors}

The seven financial risk factors were identified. The financial ratios from the balance sheets were grouped as factors used for factor analysis. The seven financial risks were identified are interest risk factor, liquidity risk factor, credit risk factor, solvency risk factor, stock price risk factor, market risk factor and exchange risk factor.

In this study, the following ratios were used to measure the seven financial risks.

Interest rate risk, Ir : Short Term Liability/ Total liability;

Liquidity risk, $L r$ : Net loans / Total assets;

Credit risk, $\mathrm{Cr}$ : Loan loss reserve / Gross loans;

Solvency risk, $\mathrm{Sr}$ : Total capital ratio;

Stock price risk, $\sigma_{i}$ : Standard deviation of stock returns;

Market risk, $\sigma_{m}$ : Standard deviation of market returns;

Exchange rate risk, $E_{i}$ : Standard deviation of exchange rate of Renminbi (RMB, Yuan) to United States dollar (USD, \$).

The relation between abnormal return as dependent variable and unexpected earnings, interest rate risk, liquidity risk, credit risk, solvency risk, stock price risk, market risk and exchange rate risk as independent variables were tested in the regression:

$$
C A R_{i}=\lambda_{0}+\lambda_{1} U E_{i}+\lambda_{2} I r_{i}+\lambda_{3} L r_{i}+\lambda_{4} C r_{i}+\lambda_{5} S r_{i}+\lambda_{6} \sigma_{i}+\lambda_{7} \sigma_{m}+\lambda_{8} E i+\varepsilon_{i}
$$


Nine simple regressions were performed according to equation (3).

The research question is to identify these factors whether have the information content over and above the information from the earnings disclosures (UE). The panel ordinary least square regression was used for regressions and determined the key factors to be more significantly in adding information to price determinants.

\section{Data Collection}

The China commercial banks data set was organized from the monthly closing prices, annual earnings and balance sheets information in the sources: Bankscope, financial data in the China Stock Exchange; the financial information from the Company Annual Reports; and the annual earnings announcements obtained from China Stock Exchange website.

Table 1

Total Assets, Deposits, Equity, Loans and Income of Selected Banks in 2008 (RMB' Million)

\begin{tabular}{|c|c|c|c|c|c|c|}
\hline No & Bank & Total assets & Deposits \&S-T funding & Equity & Loans & Net income \\
\hline 1 & Bank of Nanjing & 93,716 & 77,198 & 11,296 & 39,057 & 1,456 \\
\hline 2 & Bank of Ningbo & 103,263 & 87,570 & 8,805 & 48,466 & 1,332 \\
\hline 3 & Bank of Beijing Co Ltd & 417,021 & 33,814 & 365,451 & 187,690 & 5,417 \\
\hline 4 & Shenzhen Development Bank Co Ltd & 474,440 & 442,873 & 16,401 & 281,715 & 614 \\
\hline 5 & Hua Xia Bank & 731,637 & 666,039 & 27,421 & 345,668 & 3,071 \\
\hline 6 & Industrial Bank Co Ltd & $1,020,899$ & 886,354 & 49,022 & 489,986 & 11,385 \\
\hline 7 & China Minsheng Banking Corporation & $1,050,141$ & 946,158 & 53,810 & 646,443 & 7,831 \\
\hline 8 & China CITIC Bank Corporation Ltd & $1,188,152$ & $1,056,360$ & 95,661 & 651,352 & 13,354 \\
\hline 9 & Shanghai Pudong Development Bank & $1,309,425$ & $1,199,950$ & 41,702 & 681,267 & 12,516 \\
\hline 10 & China Merchants Bank Co Ltd & $1,571,797$ & $1,420,232$ & 79,781 & 852,754 & 20,946 \\
\hline 11 & Bank of Communications Co.Ltd & $2,682,947$ & $2,445,281$ & 150,095 & $1,298,776$ & 28,490 \\
\hline 12 & Bank of China Limited & $6,951,680$ & $5,972,449$ & 489,887 & $3,189,652$ & 65,894 \\
\hline 13 & China Construction Bank Corporation & $7,555,452$ & $6,867,357$ & 467,562 & $3,683,575$ & 92,642 \\
\hline 14 & Indust. \& Commercial Bank of China & $9,757,146$ & $8,900,520$ & 606,630 & $4,436,011$ & 111,226 \\
\hline \multicolumn{2}{|r|}{ Total } & $34,907,717$ & $31,002,155$ & $2,463,524$ & $16,832,412$ & 376,173 \\
\hline \multicolumn{2}{|c|}{ Average } & $2,493,408$ & $2,214,440$ & 175,966 & $1,202,315$ & 26,869 \\
\hline
\end{tabular}

Data from year 2002-2008 were used and the population of sample consisted of 14 listed and traded banks over the test period. Table 1 shows the general information about these 14 banks in year 2008. These banks are Bank of Nanjing, Bank of Ningbo, Bank of Beijing Co Ltd, Shenzhen Development Bank Co Ltd, Hua Xia Bank, Industrial Bank Co Ltd, China Minsheng Banking Corporation, China CITIC Bank Corporation Limited, Shanghai Pudong Development Bank Co. Ltd, China Merchants Bank Co Ltd, Bank of Communication Co. Ltd., Bank of China Ltd., China Construction Bank Corporation, Industrial \& Commercial Bank of China (ICBC).

Table 1 shows the banks total assets, deposits, equity, income and loans of selected banks in 2008. The sample consists of banks whose total assets vary from RMB 93 billion (Bank of Nanjing) to RMB 9,757 billion (Industrial \& Commercial Bank of China). The average total asset is RMB 2,493 billion.

\section{Findings and Discussion}

\section{Returns-to-Earnings for Banks}

Table 2 shows the regression results of the returns-to-earnings relation of the fourteen banks in the period 2002 to 2008. The regressions are between risk-adjusted cumulative abnormal returns as dependent variable 
and the unexpected annual earnings, the seven risk factors as the independent variables. To estimate the returns to earnings relation, the independent variables were regressed one by one. The results in Table 2 are shown the first eight regression models then follow by a final regression model which consists of all the independent variables that significantly affect the returns-to-earnings relation.

From the model 1, the regression result indicates that the coefficient for UE is positive. The value for UE coefficient is 0.188 and its $t$-statistic is 2.331 , which is significant at 0.05 level. The $R$-square in model 1 is 0.133. The 14 banks exhibited strong return-to-earnings relation.

Table 2

Regression Results for Returns-to-Earnings Relation for Banks in China From Period 2004 to 2008

\begin{tabular}{|c|c|c|c|c|c|c|c|c|c|}
\hline \multirow{2}{*}{$\begin{array}{l}\text { Independent } \\
\text { variable }\end{array}$} & \multicolumn{9}{|c|}{ Model } \\
\hline & 1 & 2 & 3 & 4 & 5 & 6 & 7 & 8 & 9 \\
\hline \multirow[t]{3}{*}{ Constant, $\lambda_{0}$} & -0.136 & -0.03 & -0.011 & -0.01 & -0.02 & -0.046 & -0.112 & -0.07 & -0.513 \\
\hline & $(-2.857)$ & $(-0.069)$ & $(-0.313)$ & $(-0.041)$ & $(-0.053)$ & $(-0.356)$ & $(-1.297)$ & $(-0.167)$ & $(-1.955)$ \\
\hline & $(0.08)$ & $(0.946)$ & $(0.757)$ & $(0.968)$ & (0.958) & $(0.724)$ & $(0.205)$ & $(0.869)$ & $(0.061)$ \\
\hline \multirow[t]{3}{*}{$\mathrm{UE}, \lambda_{I}$} & 0.188 & & & & & & & & 0.200 \\
\hline & (2.331) & & & & & & & & (2.519) \\
\hline & $(0.027 *)$ & & & & & & & & $(0.018 *)$ \\
\hline Interest & & 0.121 & & & & & & & \\
\hline \multirow[t]{2}{*}{ Risk, $\lambda_{2}$} & & $(0.528)$ & & & & & & & \\
\hline & & $(0.602)$ & & & & & & & \\
\hline Liquidity & & & -0.654 & & & & & & -0.570 \\
\hline \multirow[t]{2}{*}{ Risk, $\lambda_{3}$} & & & $(-2.068)$ & & & & & & $(-1.460)$ \\
\hline & & & $(0.048 *)$ & & & & & & $(0.046 *)$ \\
\hline Credit & & & & -0.05 & & & & & \\
\hline \multirow[t]{2}{*}{ Risk, $\lambda_{4}$} & & & & $(-0.423)$ & & & & & \\
\hline & & & & $(0.675)$ & & & & & \\
\hline Solvency & & & & & -0.132 & & & & \\
\hline \multirow[t]{2}{*}{ Risk, $\lambda_{5}$} & & & & & $(-1.051)$ & & & & \\
\hline & & & & & $(0.302)$ & & & & \\
\hline Price & & & & & & -0.398 & & & \\
\hline \multirow[t]{2}{*}{ Risk, $\lambda_{6}$} & & & & & & $(-0.371)$ & & & \\
\hline & & & & & & $(0.713)$ & & & \\
\hline Market & & & & & & & -1.62 & & \\
\hline \multirow[t]{2}{*}{ Risk, $\lambda_{7}$} & & & & & & & $(-1.417)$ & & \\
\hline & & & & & & & $(0.167)$ & & \\
\hline Exchange & & & & & & & & -5.212 & \\
\hline \multirow[t]{2}{*}{ Risk, $\lambda_{8}$} & & & & & & & & $(-0.334)$ & \\
\hline & & & & & & & & $(0.741)$ & \\
\hline Adj $R$-sq & 0.133 & -0.011 & 0.102 & -0.029 & 0.004 & -0.031 & 0.034 & -0.032 & 0.166 \\
\hline \multirow[t]{2}{*}{$F$-Stat } & 5.435 & 0.675 & 4.278 & 0.179 & 1.104 & 0.138 & 2.009 & 0.112 & 3.893 \\
\hline & $(0.027 *)$ & $(0.418)$ & $(0.048 *)$ & $(0.675)$ & $(0.302)$ & $(0.713)$ & $(0.167)$ & $(0.741)$ & $(0.033 *)$ \\
\hline DW & 2.137 & 2.181 & 2.223 & 2.128 & 2.257 & 2.13 & 1.901 & 2.190 & 2.205 \\
\hline
\end{tabular}

Notes. Number in each bracket is $t$-statistic and $p$-value, significant at $(*) 0.05$ level. 


\section{Risk Determinants of the Returns-to-Earnings Relation for Banks}

The seven risk factors were subsequently added one by one into the regression of risk adjusted cumulative abnormal returns and unexpected annual earnings. Model 2, model 4, model 5, model 6, model 7 and model 8 show the coefficient for interest risk, credit risk, solvency risk, stock risk, market risk and exchange rate risk factors are insignificant, except the coefficient for liquidity risk factor in model 3. Model 3 indicates that the coefficient of the liquidity risk factor has a $t$-statistic of -2.068 and a $p$-value of 0.048 which is significant at 0.05 level. The coefficient of the liquidity risk factor has a negative sign which shows that the lower the bank liquidity risk factor the banks have the lower ability to fund their financial needs. It also mean that for banks that are having the same unexpected earning and the one with lower/higher liquidity risk, the higher/lower the investor's valuation of the bank share prices in response to the earnings changes.

The model 9 indicates the coefficient for the liquidity risk factor has a $t$-statistic 1.460 and a $p$-value of 0.046. This result suggests that within $95 \%$ confidence, the coefficient for liquidity risk factor is greater than being zero. Therefore, liquidity risk factor is to be taken as indicating as having a directional and also a magnitude effect after the earning variable.

In this study, there is no econometric problem and the data used are pooled data. Therefore, these data do not have auto correlation problem. The Durbin-Watson statistics lie between 1.901-2.257 shows that the data do not have autocorrelation problem. The values of Variance Inflation Factors (VIF) lie between 1.00-1.10, which are below significant level. Hence, there is no multicollinearity problem. Generally, there is no econometric problem and the residuals do not display serial correlation or heteroscadesticity.

\section{Conclusion}

The main purpose of this paper is to study the effect of financial risks on the earnings response coefficients for selected China commercial banks. The findings in this study for China provide new evidences in different and unique way related to its particular historical background and government decision on economy.

This study discovers that liquidity risk has information content beyond earnings for China banks. In this paper, there was a negative sign for liquidity risk which means when liquidity risk increases, the share response to earnings of the banks decreases. There is a trade off between liquidity and profitability. The finding in this study is consistent with the general theory on assets-liabilities management of banks. Managers of banks find the level of liquidity that fulfilled the need of investors and at the same time earn good profits for the banks.

In conclusion, this study has shown the strong returns-to-earnings relation for banks. The liquidity risk has information content beyond earnings changes in the returns-to-earnings relation. Whereas the other 6 risk factors were not significant probably due to the reason that firstly, the investors were not concerned with the other factored risk variables. Secondly, the banks were very well managed by their managers that the other financial risk variables are stable to have no significant effect on share value.

\section{References}

Ariff, M., Loh, A. L. C., \& Chew, P. M. K. (1997). The impact of accounting earnings disclosures on stock prices in Singapore. Asia Pacific Journal of Management, 14, 17-29.

Ball, R., \& Brown, P. (1968). An empirical evaluation of accounting income numbers. Journal of Accounting Research, 6, 159-178.

Ball, R., Kothari, S. P., \& Watts, R. L. (1993). Economic determinants of the relation between earnings changes and stock returns. The Accounting Review, 68(3), 622-638. 
Barajas, A., Chami, R., Cosimano, T., \& Hakura, D. (2010, April). Commercial bank behavior in the wake of the 2007-2009 financial crisis (Working paper, IMF Institute and Middle East and Central Asia Department, 2010).

Beaver, W. H., Clarke, R., \& Wright, W. (1979). The association between unsystematic security returns and the magnitude of earnings forecast errors. Journal of Accounting Research, 17, 316-340.

Bystrom, H., Worasinchai, L., \& Chongsithipol, S. (2005). Default risk, systematic risk and Thai firms before, during and after the Asian crisis. Research in International Business and Finance, 19, 95-110.

Cheng, F. F., \& Ariff, M. (2007). Abnormal returns of bank stocks and their factor-analyzed determinants. Journal of Accounting, Business \& Management, 14, 1-16.

Cheng, F. F., Arif, M., \& Shamsher, M. (2001). Accounting earnings and share revaluation: Further exploration. Capital Market Review, 9(2), 21-48.

Choi, J. J., Elyasiani, E., \& Kopecky, K. J. (1992). The sensitivity of bank stock returns to market, interest and exchange rate risks. Journal of Banking and Finance, 16, 983-1004.

Dennis, S. A., \& Jeffrey, A. (2002). Structural changes in Australia bank risk. Journal of International Financial Market, Institutions and Money, 12, 1-17.

Faff, R. W., \& Howard, P. F. (1999). Interest rate risk of Australia financial sector companies in period of regulatory change. Pacific-Basin Finance Journal, 7, 83-101.

Giliberto, M. (1985). Interest rate sensitivity in the common stocks of financial intermediaries. Journal of Financial and Quantitative Analysis, 20, 123-126.

Hagerman, R. L., Zmijewski, M. E., \& Shah, P. (1984). The association between the magnitude of quarterly earnings forecast errors and risk-adjusted stock returns. Journal of Accounting Research, 22(2), 526-540.

Sharpe. (1964). Capital asset prices: A theory of market equilibrium under conditions of risk. Journal of Finance, 19, 425-442.

Yang, X. (2002). General financial history of China. Beijing: China Finance Publishing House. 